
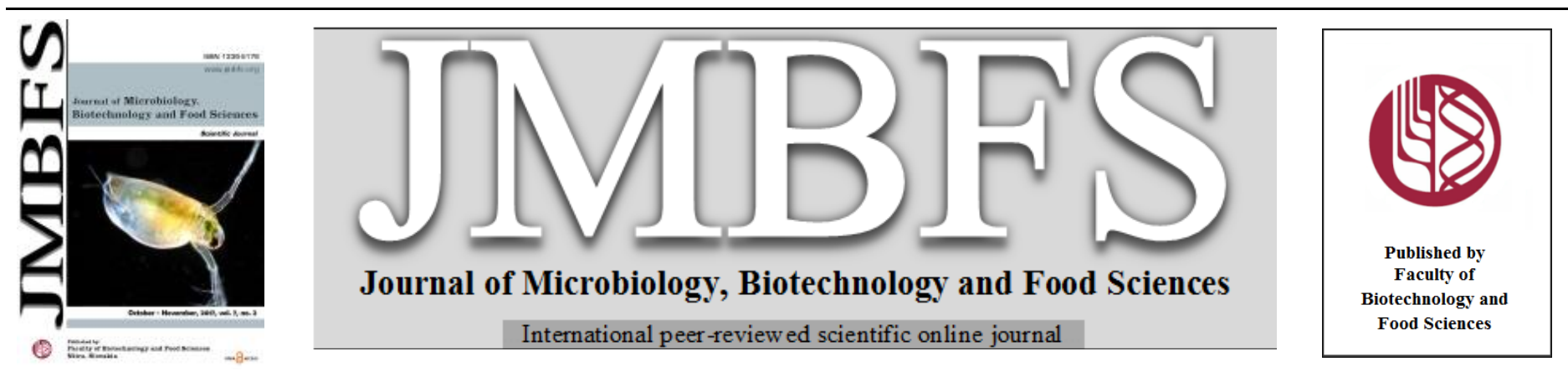

\title{
QUALITY OF BOVINE PREIMPLANTATION EMBRYOS IN RELATION TO CATTLE BREED
}

\author{
Alexander V. Makarevich ${ }^{l}$, Elena Kubovičoval, Peter Chrenek $^{1,2}$ \\ Address(es): \\ ${ }^{1}$ National Agricultural and Food Centre, Research Institute for Animal Production Nitra, Hlohovecká 2, 95141 Lužianky near Nitra, Slovak Republic. \\ ${ }^{2}$ Faculty of Biotechnology and Food Science, Slovak University of Agriculture, Tr.A.Hlinku 1, 94901 Nitra, Slovak Republic.
}

*Corresponding author: makarevic@vuzv.sk

doi: 10.15414/jmbfs.2017.7.2.143-144

\section{ARTICLE INFO}

Received 2. 9. 2016

Revised 7. 10. 2016

Accepted 11. 9. 2017

Published 1. 10. 2017

Short communication

open 2 access

\begin{abstract}
The aim of this study was to compare quality of bovine preimplantation embryos recovered from cows of three cattle breeds bred in Slovakia: Holstein $(n=38)$, Pinzgau $(n=28)$ and Slovak Pied $(n=53)$. Total number of embryo cells (DAPI-stained nuclei) and incidence of dead cells (TUNEL-positive nuclei) were counted in total of 563 bovine blastocysts collected from three breeds under the Leica fluorescent microscope. This study was done in 12 experiments performed during seven years. The lowest total number of embryo cells was counted in Pinzgau cattle (107 \pm 8.5$)$ and the highest - in Holstein cows $(121 \pm 5.5)$, whilst in Slovak Pied cows the embryo cell number was at moderate value $(112 \pm 6.4)$. The highest dead cell index $(\%)$ was calculated in embryos from Pinzgau cattle $(6.22 \pm$ 0.57), whilst Holstein and Slovak Pied embryos showed almost similar values (5.72 \pm 0.34 and $5.31 \pm 0.49$, resp.). However, in both cases these differences among the breeds were statistically insignificant. In conclusion, present study did now reveal an influence of cattle breed on the quality of bovine preimplantation embryos. These findings may have an importance at the realization of genetic resource preservation program in Slovakia.
\end{abstract}

Keywords: Cattle, breed, embryo, cell number, apoptosis

\section{INTRODUCTION}

Decline in the genetic diversity of livestock is the result of intense genetic selection of a narrow range of commercial and reproductive characteristics of animals (Buerkle, 2007). Protection of genetic diversity of domesticated animals and endangered wildlife is a global issue, important from a biological, economical and moral viewpoint (Prentice and Anzar, 2011). Gene banks are a valuable tool in programs focused on the improvement of livestock breeding, where the population control is essential in order to record actual genetic gain or to protect selected animal breeds. In this relation the monitoring of the quality of cattle embryos intended to be stored in the gene bank is an actual task.

The results of embryo transfer are variable among breeds of donor cows (Donaldson, 1984). On the other hand, in in vitro produced bovine embryos, paternal breed of cows did not influence cleavage, blastocyst rate and relative abundance of IGF-II and the apoptosis-related genes (BCL2 and BAK1) in day 8 blastocysts (Valleh et $\boldsymbol{a l}$., 2015). Nevertheless, cattle breed was seen to affect early embryo development during in vitro embryo production, when Swedish cattle were used as an oocyte donor (Abraham et al., 2012). In particular, significant differences between Swedish red and Swedish Holstein breeds in percentage of day 8 blastocysts as well as in embryo cell number were observed (Abraham et al., 2012). Results from different studies showed that crosses of Holstein and Scandinavian red breeds had better fertility than purebred Holstein cows (Heins et al., 2006).

It seems also, that variability in fertility outcomes among the breeds can be influenced by the region of cattle origin. There are some evidence about differences between breeds in response of preimplantation embryos to heat shock. In particular, cow embryos from thermoresistant breeds Brahman and Romosinuano are more resistant to heat shock $\left(41^{\circ} \mathrm{C}\right.$ for 6 hours) than embryos from thermosensitive breeds Holstein or Angus (Paula-Lopez et al., 2003; Hernandez-Ceron et al., 2004).

Generally, morphological and functional criteria including embryo cell number, apoptotic cell rate, level of fragmentation, cytoskeleton status, embryo diameter, developmental stage and others, are the most common parameters of the evaluation of preimplantation embryo quality (Van Soom and Boerjan, 2002).

The aim of this study was to check quality of bovine preimplantation embryos recovered from three cattle breeds located in Slovakia: Holstein, Pinzgau and Slovak Pied. We analysed embryo yield, embryo cell number and incidence of dead (apoptotic/necrotic) cells in 563 bovine blastocysts.

\section{MATERIAL AND METHODS}

\section{Preparation of animals and embryo recovery}

In our experiments preimplantation stage embryos $(n=563)$ were recovered from cows of Holstein $(n=38)$ Pinzgau $(n=28)$ and Slovak Pied $(n=53)$ breeds. All cows selected for observation were without reproductive disorders in evaluated period as well as previous lactations. The ovarian functions were examined using ultrasound machine ALOKA SSD-500 (Aloka Co., Ltd., Tokyo, Japan) equipped with a $5-\mathrm{MHz}$ array probe before hormonal treatment. Only cows with corpus luteum were selected for subsequent ovarian cycle synchronization and superovulation.

The oestrus of cows was synchronized by the injection of a $\mathrm{PGF}_{2 \text { alfa }}$ analogue OESTROPHAN (Bioveta a.s., Ivanovice na Hane, Czech Republic) after ultrasound examination at the day 0 . The cows were superovulated by application of porcine pituitary gonadotropin (PLUSET ${ }^{\mathbb{R}}$ - FSHp-LHp , Lab CALIER, Barcelona, Spain) twice daily during 5 days at 8.00 and 20.00 hours (given in a decreasing dosage rate; starting with the doses of $150 \mathrm{IU}$ FSH $+150 \mathrm{IU}$ LH in the morning at the $11^{\text {th }}$ day to $50 \mathrm{IU}$ FSH+50 IU LH in the evening at the $15^{\text {th }}$ day) of the oestrous cycle. Oestrophan was administered for luteolysis at the $13^{\text {th }}$ day. One insemination and re-insemination were performed during the $17^{\text {th }}$ day by the same AI technician with frozen-thawed AI doses from one sire only at 12 hrs intervals. The insemination was done at the standing oestrous, while reinsemination was performed 12 hrs later. Embryo recovery was performed on $7^{\text {th }}$ day after the first insemination by a standard non-surgical technique to flush out the uterine horns. Uterine flushing was conducted with a complete flush solution (BIONICHE, Belleville, Ontario, Canada) using a silicone two-way Foley catheter (MINITÜB GmbH, Tiefenbach, Germany). Flushed ova/embryos were transferred to the holding medium - phosphate buffered solution (PBS) with 20\% foetal calf serum (FCS, Gibco BRL) and assessed using a stereomicroscope.

\section{Evaluation of embryos}

The embryos were evaluated according to their stage of development (morulas, blastocysts, fragmented/degenerated embryos, unfertilized oocytes). Thereafter, the embryo quality was estimated on the basis of average embryo cell number and apoptosis index. Apoptotic indexes were determined on the basis of proportion of TUNEL-positive nuclei (green fluorescence) to total embryo cell 
number (DAPI-stained nuclei), which have been counted under the Leica fluorescent microscope (LEICA Microsystems, Germany) using specific wavelength filters. The TUNEL-positive nuclei are considered as the dead cell nuclei. Briefly, the embryos $(n=563)$ were washed 3-times for 5 min in PBS-PVP washing solution (PBS with $4 \mathrm{mg}^{-\mathrm{ml}^{-1}}$ polyvinylpyrrolidone; Sigma-Aldrich Chemie, Steinheim, Germany). Then the embryos were fixed in $3.7 \%$ neutrally buffered formalin (Fluka, Buchs, Switzerland) for $10 \mathrm{~min}$. Permeabilization was done by 1 hour incubation of embryos in $0.5 \%$ Triton X-100 in PBS. Afterward, the embryos were processed for the cell death detection (TUNEL) using In situ CELL DEATH DETECTION KIT (Roche Slovakia Ltd, Bratislava, Slovak Republic) according to the product manual. Briefly, fixed and permeabilized embryos were incubated at $37^{\circ} \mathrm{C}$ in the TUNEL-detecting solution, consisted of fluorescence-labelled nucleotides (dUTP-FITC, 37 $\mu$ l) and terminal transferase (TdT, $3 \mu \mathrm{l}$ ), at $37^{\circ} \mathrm{C}$ for $1 \mathrm{~h}$. As a positive control for TUNEL, a group of fixed and permeabilized embryos was incubated in the presence of bovine DNase I for 1 hour at $37^{\circ} \mathrm{C}$ before the TUNEL reaction. Following this incubation TUNELreaction was stopped by three-time washing of embryos in PBS-PVP solution.

\section{Statistics}

The experiment was performed in 12 replications. A one-way ANOVA and Tukey-test were used to analyze differences in TUNEL-index between groups Since variable "TUNEL-index" was normally distributed, a log-transformation of original values was not done. The hypothesis of normality was rejected for "TUNEL cells per embryo" and for "Embryo cell number". For these two variables data were log-transformed. All calculations were performed using the SAS software package (SAS Institute, 2001).

\section{RESULTS AND DISCUSSION}

This study summarizes results of 12 experiments on cattle embryo recovery performed during 7 years. Totally, 563 bovine embryos at the blastocyst stage (early blastocyst, blastocyst and expanded blastocyst) recovered from three cattle breeds were evaluated in this study. Table 1 shows that the lowest total number of embryo cells was counted in Pinzgau cattle and the highest - in Holstein cows, whilst in Slovak Pied cows the embryo cell number was at moderate value Nevertheless, these differences among the breeds were statistically insignificant.

Table 1 Quality of bovine blastocysts in relation to cattle breed

\begin{tabular}{lccc}
\hline Breed & $\begin{array}{c}\text { No. } \\
\text { blastocysts }\end{array}$ & $\begin{array}{c}\text { Embryo cell } \\
\text { number, } \mathrm{n}\end{array}$ & Apoptotic index, \% \\
\hline Holstein & 187 & $121 \pm 5.5$ & $5.72 \pm 0.34$ \\
Pinzgau & 128 & $107 \pm 8.5$ & $6.22 \pm 0.57$ \\
Slovak Pied & 248 & $112 \pm 6.4$ & $5.31 \pm 0.49$
\end{tabular}

Legend: Values of „Embryo cell number“ and „Apoptotic index“ are represented as the mean \pm S.E.M.

Concerning dead cell occurrence, calculated on the basis of proportion of TUNEL-positive cells to total cell number, the highest apoptotic index was calculated in embryos from Pinzgau cattle, whilst Holstein and Slovak Pied embryos showed almost similar values. However, there were no statistically significant differences among the breeds examined.

The data of this seven year study revealed that bovine blastocysts do not differ in their quality among three analysed breeds bred in Slovakia: Holstein, Pinzgau and Slovak Pied. Pinzgau and Slovak Pied are the local breeds representing gene resources (diversity) in this area, whilst Holstein cattle was imported to Slovakia approximately 45 years ago. These breeds are substantially differed in their milk performance. According to the report of Animal Breeding Service of the Slovak Republic, average milk yield per lactation is 4500,6000 and $8300 \mathrm{~kg}$ per cow for Pinzgau, Slovak Pied and Holstein breed, respectively (www.pssr.sk). It is known that high performance can affect reproductive characteristics in cattle.

There is a discrepancy in the reproductive performance between different cattle breeds indicating better fertility in beef breeds compared to dairy breeds (Oltenacu et al., 1991; Santos et al., 2004). However, differences in fertility have even been observed between dairy breeds (Garmo et al., 2008; Keskin et al., 2011). Reasons for such differences may be most likely in different milk yield among the breeds, because higher milk yield may cause larger metabolic stress. In our case, when cattle of individual breeds substantially differ in milk yield, it may have some impact on several fertility parameters. However, even though these breeds are substantially differ in their average milk yield, these differences were not reflected in the quality of preimplantation embryos in our study. Although, our results revealed certain differences in values of total embryo cell number and apoptosis occurrence, these differences were not statistically different.

We analysed three different breeds of dairy cattle and did not find significant differences in embryo quality among them, in contrast to other studies (Abraham et al., 2012; Heins et al., 2006; Hernandez-Ceron et al., 2004; Paula-Lopes et al., 2003). This may be explained by the fact that all three cattle breeds are located at the same area of Slovakia, which is relatively small country in the territory with almost similar climate, geographical conditions, zootechnical and veterinary conditions, as well as similar plane of nutrition.

\section{CONCLUSION}

We have found that bovine preimplantation embryos did not differ in their quality among three different cattle breeds located in Slovakia. These results may be taken in consideration at the realization of local programs of genetic resource preservation.

Acknowledgments: This study was realized with the funding from the Agency for the support of Science and Technology in the Slovak Republic: grants APVV 0137 and APVV-14-0043, as well as from the Ministry of Agriculture and Rural Development of the Slovak Republic: the grant RPVV3 "Sustainability of animal biodiversity in the Slovak Republic".

\section{REFERENCES}

Abraham, M.C., Gustafsson, H., Ruete, A. \& Brandt, Y.C.B. (2012). Breed influences on in vitro development of abattoir-derived bovine oocytes. Acta $\begin{array}{llllll}\text { Veterinaria } & \text { Scandinavica, } & 54 & (36), & 6 & \text { pp. }\end{array}$ http://www.actavetscand.com/content/54/1/36

Buerkle, T. (2007). FAO sounds alarm on loss of livestock breeds. Food and Agriculture Organization of the United Nations. http://www.fao.org/.

Donaldson, L.E. (1984). Cattle breed as a source of variation in embryo transfer. Theriogenology, 21 (6), 1013-1018. http://dx.doi.org/10.1016/0093691X(84)90396-0

Garmo, R.T., Refsdal, A.O., Karlberg, K., Ropstad, E., Waldmann, A., Beckers, J.F. \& Reksen, O. (2008). Pregnancy incidence in Norwegian red cows using non-return to estrus, rectal palpation, pregnancy-associated glycoproteins, and progesterone. Journal of Dairy Sciences, 91, 3025-3033. http://dx.doi.org/10.3168/jds.2007-0778

Heins, B.J., Hansen, L.B. \& Seykora, A.J. (2006). Fertility and survival of pure Holsteins versus crossbred of Holstein with Normande, Montbeliarde, and Scandinavian Red. Journal of Dairy Sciences, 89, 4944-4951. DOI: http://dx.doi.org/10.3168/jds.S0022-0302(06)72545-0

Hernández-Cerón, J., Chase, C.C. Jr. \& Hansen, P.J. (2004). Differences in heat tolerance between preimplantation embryos from Brahman, Romosinuano, and Angus Breeds. Journal of Dairy Sciences, 87 (1), 53-58. http://dx.doi.org/10.3168/jds.S0022-0302(04)73141-0

Keskin, A., Yilmazbas-Mecitoglu, G., Gumen, A., Karakaya, E., Celik, Y., Okut, H. \& Wiltbank, M.C. (2011). Comparison of responses to Ovsynch between Holstein-Friesian and Swedish Red cows. Journal of Dairy Sciences, 94, 1784 1789. http://dx.doi.org/10.3168/jds.2010-3579

Oltenacu, P.A., Frick, A. \& Lindhé B. (1991). Relationship of fertility to milk yield in Swedish cattle. Journal of Dairy Sciences, 74, 264-268. DOI: http://dx.doi.org/10.3168/jds.S0022-0302(91)78169-1

Paula-Lopes, F.F., Chase, C.C., Al-Katanani, Y.M., Krininger, C.E. et al. (2003) Genetic divergence in cellular resistance to heat shock in cattle: differences between breeds developed in temperate versus hot climates in responses of preimplantation embryos, reproductive tract tissues and lymphocytes to increased culture temperatures. Reproduction, 125, 285-294. doi: 10.1530/rep.0.1250285

Santos, J.E.P., Thatcher, W.W., Chebel, R.C., Cerri, R.L.A. \& Galvão, K.N. (2004). The effect of embryonic death rates in cattle on the efficacy of estrus synchronization programs. Animal Reproduction Science, 82, 513-535. http://dx.doi.org/10.1016/j.anireprosci.2004.04.015

Prentice, J.R. \& Anzar, M. (2011). Cryopreservation of mammalian oocyte for conservation of animal genetics. Veterinary Medicine International, 2011, $11 \mathrm{pp}$ http://dx.doi.org/10.4061/2011/146405

Valleh, M.V., Tahmoorespur, M., Joupari, M.D., Dehghani, H., Rasmussen, M.A., Hyttel, P. \& Strobech L. (2015). Paternal breed effects on expression of IGF-II, BAK1 and BCL2-L1 in bovine preimplantation embryos. Zygote, 23 (5), 712-721. DOI: http://dx.doi.org/10.1017/S0967199414000367 (About DOI)

Van Soom, A. \& Boerjan, M. (2002). Assessment of mammalian embryo quality. Invasive and non-invasive techniques. Kluwer Academic Publishers, Dordrecht/ Boston/London, $406 \mathrm{p}$. 